Article

\title{
Exploring Critical Success Factors for Public Private Partnership Case Study: The Educational Sector in Egypt
}

\author{
Riham Helmy *, Nevien Khourshed, Mohamed Wahba and Alaa Abd El Bary
}

Department of Marketing and International Business, The Arab Academy for Science and Technology \& Maritime Transport, Alexandria 1029, Egypt; nevienkhourshed@aast.edu (N.K.); Mwahba@aast.edu (M.W.); aaelbary@aast.edu (A.A.E.B.)

* Correspondence: rihamhelmy11@yahoo.com; Tel.: +20-010-2359-4988 or +20-12-2223-0617

Received: 8 October 2020; Accepted: 6 November 2020; Published: 12 November 2020

\begin{abstract}
This research aims to explore and identify the critical success factors (CSFs) needed to facilitate and guarantee the implementation of successful public private partnership (PPP) projects in the education sector in Egypt. Thus, the research proposed a CSFs model based on an exhaustive literature review to identify CSFs for PPPs' successful implementation. The identified 21 CSFs were divided into four groups: political, legal, economic and financial as well as operational and managerial. A qualitative and quantitative analysis that involved semi-structured interviews and a questionnaire survey tool was applied to gather required data. Then, data were analyzed using the Nvivo program, correlation, and structural equation modeling (SEM) to test the hypothesis for the research. The results showed that the set of four CSFs groups which are political, legal, economic and financial as well as managerial and operational have positive significant impacts on successful PPP implementation in education in Egypt. Results also show that managerial and operational factors are the most significant factors followed by legal factors, political factors, then economic and financial factors. Finally, it is worth mentioning that the research findings provide the private sector investor with the direction, clarity and guidance essential to create the confidence needed to invest in the education market and programs in Egypt. It also provides public sector employees with a clear vision for the environment and conditions needed to embrace PPP projects in the sector of education in Egypt.
\end{abstract}

Keywords: public private partnership (PPP); managerial and operational factors; economic and financial factors; legal factors and political factors

\section{Introduction}

Egypt is one of those countries that have started to include in its strategic planning partnership with the private sector as a tool adopted to develop and improve the educational system [1]. Public private partnership (PPP), as a tool for reforming the field of education in Egypt, is not new. In 2006, the Egyptian Education Initiative (EEI) suggested through the World Economic Forum (WEF) facilitating the engagement of transnational corporations (TNCs), especially those in the information communication technology (ICT) industry, within the education sector in Egypt and other developing countries. Such partnership has been framed as a key education reform strategy to bring Egyptian students into the international labor market [2]. However, mainly external players and especially international organizations and communication corporates have driven such initiatives.

Recently, the policy of the Egyptian government and especially that of education has witnessed many changes. These changes are driven by internal factors, especially the urgent need for reform and development. These changes are stated clearly in the state's vision strategy 2030, policies as well as 
newly formulated and amended laws. For example, Egypt's vision strategy 2030 stated explicitly that the government aims at expanding the role of private and civil society in the educational process and its development [1]. Moreover, in 2016, the central unit of PPP in the Ministry of Finance launched the national project for construction and operation of language schools in partnership with the private sector. The contracts signed in 2019, which comprise the first phase of this project, include the construction of 910 classrooms at a total cost of LE 500 million [3]. Furthermore, in 2019, the Ministry of Higher Education and Scientific Research represented by Ain Shams University invited interested companies/consortia to compete to enter into a PPP contract to design, finance, build, equip, maintain and provide some non-educational services of the new building for Faculty of Commerce Ain Shams University in El-Obour City. In addition to the initiative of Education for Employment (E4E) that has started with Americana Group, this process has continued by with the launch of a number of vocational schools in partnership with the private sector.

Furthermore, a new education system was launched in 2018 for pre-university education. In addition, several laws that relate to higher education have been enacted and amended as law no. 28 of 2018 on the incentives for science, technology and innovation. These developments indicate that the new vision and policies of the Egyptian government aim at collaborating with the private sector to develop and reform the entire education sector i.e., pre-university education and higher education.

Nevertheless, to the best of the researchers' knowledge, no studies have been undertaken into analyzing the role and impact of this tool on the education sector in Egypt. Only one study has been conducted by Afridi in 2017. The study investigated how PPP was a vehicle for promoting the involvement of transnational corporations in education sector reforms. Moreover, the study raised many important questions about the impact of such PPPs in addressing access, quality, equality, and social justice issues in education. However, in spite of the importance of the social issues raised by the study of Afridi [1], resorting to PPP has become an indispensable tool in developing the Egyptian educational system. This is because Egypt's weak and crumbling educational system suffers from several issues. It is extremely underfunded, overpopulated and not responding to market needs [2,4]. Consequently, it is not a surprise that policy reforms focus on increasing private sector and community participation to supplement state efforts in the provision of education. In particular, PPP can increase efficiency in the delivery of services and consequently activate the direction of additional resources to the provision for education. It can also increase quality of service to match market needs and generate competition in the education market [5].

However, to ensure that PPP in education can succeed and achieve its goals, it is important to provide the suitable and appropriate factors critical for its successful implementation. Accordingly, it is important to carry out further research to investigate how PPP in education could be managed and controlled in a way that would benefit all stakeholders and form successful PPP projects that would have a positive impact on the development of the education sector in Egypt.

Hence, this research is carried out to answer the following question:

What are the critical success factors (CSFs) that guarantee the success of PPP in the education sector in Egypt? Moreover, how do these factors influence the implementation of PPP in Egypt?

To reach this aim and develop a full and precise framework reflecting the CSFs for PPPs' successful implementation, the researcher sets the objectives of this research which are to: (1) explore different views of experts and stakeholders as well as practices related to PPP implementation in the education sector in Egypt; (2) explore the CSFs for PPP successful implementation in the education sector in Egypt; (3) determine the effect of the identified CSFs on implementing PPP in the education sector in Egypt; (4) formulate recommendations on PPP successful implementation in Egypt.

For policy-makers and those engaged in such partnership, this research develops a useful framework for PPP in the educational sector in Egypt that would help to engender the necessary environment for successful PPPs. It is believed that the participants of future PPP education projects can use these findings to maximize the success of conducting similar projects. In addition, it should ensure that resources invested in PPP projects are used more effectively and produce a greater overall 
impact. This study shall also contribute to the existing literature by developing a framework to explain CSFs that influence the success and sustainability of PPP projects in education that remain poorly understood particularly in the context of developing countries such as Egypt. Academics also might benefit from this research by re-focusing their attention from a traditional survey of PPP advantages and disadvantages, or simply comparing PPP with privatization, to a more updated research agenda.

\section{Literature Review}

Many governments, international organizations and other crucial education stakeholders are increasingly recognizing PPP as an innovative policy approach to expand education systems in a more efficient, flexible and effective way [6]. However, PPP is a form of governance that is difficult, complex, and challenging both for the private agents and for governments [7]. Moreover, there is a wide range of policy options and rationales of PPP forms that locate PPP in an ambiguous policy category. Consequently, in both academic and expert circles PPP is considered a confusing policy approach because it is not obvious what PPP means exactly, for which reasons countries should adopt them, and what the best form for PPP is. Thus, the challenges of implementing PPP differ according to the country and the industrial sector [8]. This justifies the aim of this research-the necessity of identifying the CSFs specific to the successful implementation of different forms of PPP in the education sector in Egypt whether on the level of pre-university or high education. This section proceeds to review literature on the concept of PPP projects in education in Egypt and the main CSFs of PPP.

\subsection{Public Private Partnership (PPP) in Egypt}

The PPP as a political tool has been attractive on an international level and has been recently used in Egypt to introduce the private sector cooperation with the government in the reform of education. This has been done through a number of initiatives and projects that started in 2006 and have continued up until now. In 2006, the World Economic Forum (WEF) introduced a huge PPP project, called the Egypt Education Initiative (EEI). The EEI was launched as a part of the Global Education Initiative of the WEF. The aim of this Initiative is to activate initiatives of education at the international, regional and country levels by establishing multi-stakeholder partnerships, including the private sector [2].

According to the WEF report in 2007, almost 1929 middle schools have been supplied with computer laboratories and Internet connections. In addition, an initiative for training about 65,000 teachers was launched through an International Computer Driving License (ICDL) certification program [2]. Moreover, many universities and research networks (EURN) have been renovated, and the Egypt Computer 2010 Program has been expanded to involve students, teachers, and professors [2].

Moreover, effective collaboration has been held with about 25 national companies [2]. The role of international IT corporations in this initiative has taken the form of developers, suppliers, as well as educational technology suppliers. This initiative has provided these international corporations with the chance to test out new ideas, products and services with a relatively low risk, and develop strong relationships with stakeholders in the education sector in these countries [9]. The aforementioned results of the Egyptian initiative seem to achieve reasonable development in activating resources and developing the ICT skills of students and teachers [9]. However, the effect of this initiative on teaching and learning is not known. A deep and evidence-based evaluation for this initiative has not been conducted.

In 2007, the rise of the idea of corporate social responsibility (CSR) and the need to develop the educational system to meet the demands of job market were behind the appearance of what is known now as "Dual Education" and/or "Education for Employment" (E4E). Americana Group, a food service multinational company, which has started an initiative in collaboration with the Ministry of Education as well as Ministry of Higher Education [10]. This partnership resulted in the presence of a number of dual education programs. The aim of these programs was to establish an effective model for the educational system that connects educational path with career path, in accordance with the market needs [10]. The program combines the skills and standards needed by the industry as well as 
vocational training in restaurants in an educational curriculum and experience that is connected to a career path, which includes different levels entry, supervisory and management [11].

According to participants in this partnership, Americana's involvement in education has resulted in increasing fresh graduates' employability, improving graduates' profile to suit employers and market needs, upgrading learning facilities, and supplying industry with a pool of qualified fresh graduates-thus addressing the main reasons for youth unemployment [11]. The society also gains a new productive generation that is independent, responsible and competent to reshape the nation's future. Moreover, the initial positive indicators of the programs, prompted competitors such as McDonald's, Burger King and Amer group to set up similar programs [11].

This partnership expanded to reach five programs by 2011. These programs are: a two-year Advanced Diploma from Technology Colleges (2007), four-year Bachelor degree Restaurant Management and Operation Faculty of Tourism and Hotel Management-Helwan University, four-year Bachelor of Science (B.Sc.) from the Faculty of Agriculture-Business Management-Menoufeya University, four-year B.Sc. in Agriculture-Poultry Production-Damanhur University and three-year program at Technical Secondary Schools. In spite of positive indicators of these partnership programs, there are some concerns about their sustainability. Some of these programs depend on the social responsibility of companies that may be affected by the financial situation of the company and/or the economic and political situation in the country, i.e., this partnership does not represent a complete business model that would generate its own income to sustain it.

The privatization of education and the advancement of PPP continued in Egypt after 2011, as the current Egyptian government has promised to develop the education system in cooperation with the private sector [9]. This promotion of PPP appears in Egypt's vision 2030 [1], in the new enacted laws and regulations as well as the new projects and initiatives held by the competent ministries and competent bodies. For instance, several laws that relate to higher education have been enacted and amended as law no. 28 of 2018 on the incentives for science, technology and innovation. These laws allow for cooperation with private sector. These developments indicate that the new vision and policies of the Egyptian government aim at collaborating with the private sector to reform the education sector. This collaboration is stated clearly in Egypt's vision 2030 in the seventh pillar of education and training in respect of pre-university, technical and higher education. For example, in respect of higher education, the vision states that:

'The role of private and civil society should be expanded in respect to the establishment of higher education institutions and the development of joint academic programs and electronic universities, in order to achieve accessibility, the principle of equal opportunity, and reduce the burden borne by the state.' [1]

Moreover, the Ministry of Education and Technical Education (MoETE) as well as the Ministry of Higher Education and Scientific Research are holding two pilot projects with the technical assistance of the PPP central unit in the Ministry of Finance.

In September 2016, the Egyptian government announced a new PPP program for construction and operation of language schools in partnership with the private sector in an attempt to face the deep-rooted problem of classroom density in public schools and to afford good education with fair fees [3]. The contracts signed in 2019 which comprise the first phase of this project include the construction of 910 classrooms at a total cost of LE 500 million [3]. Although the supporters of this project, involving the minister of Education, claim that, this program could help middle-class families in finding inexpensive schools, and relieve the load from existing public schools. Opponents claim that the program is focusing on various demographics and, consequently, this will not influence the density of existing schools. Moreover, they claim that there are already sufficient private schools providing their services in these demographics [3]. Furthermore, in 2014, the Central Agency for Public Mobilization and Statistics (CAPMAS) published a report that stated that the areas of Upper Egypt 
and the Nile Delta are not attractive for education investors to establish private schools in and that private schools are principally founded in Cairo, Giza, and Alexandria [9].

In 2019, the Ministry of Higher Education and Scientific Research represented by Ain Shams University invited interested companies/consortia to compete to enter into a PPP contract to design, finance, build, equip, maintain and provide some non-educational services of the new building for Faculty of Commerce Ain Shams University in El-Obour City.

Furthermore, the initiative of Education for Employment (E4E) that has started with Americana Group has continued by launching a number of vocational schools in partnership with the private sector such as El Araby School for Applied Technology [12], Egypt's first jewelry-making school [13].

In addition to this, a new education system called Education 2.0 was launched in 2018 for pre-university education. This new system aims at transforming Egypt's public education system. This transformation takes place from kindergarten through grade 12, in which the essence of what is learned will be upgraded to keep pace with the challenges of the 21st century. The aim of this transformation is to change the learning experience of the students, with technology playing an essential role in educational revolution. The transformation known as Education 2.0 (EDU 2.0) started in 2018 and will continue until 2030 [14].

International organizations as UNICEF as well as other partners including UNESCO, ILO, UNFPA, UNHCR, UNRWA, the World Bank, etc. have been providing technical guidance for assisting the MoETE to integrate Life Skills and Citizenship Education (LSCE) scheme in curriculum development in addition to teacher training and materials required for reforming KG1, KG2, and Grade 1 levels [15].

The previously mentioned examples show that PPP is proposed as a policy tool in education in Egypt. Therefore, PPP success in education in Egypt needs to be investigated in relation to the history of its education system as well as the evidence-based data on PPP in weak countries. Consequently, a further literature review was held to identify the main factors that relate to PPP success in previous studies. This is discussed in the following section.

\subsection{Critical Success Factors (CSFs) of PPP}

CSFs are the few essential areas that could ensure the success of an institution or a project if available [16] and might lead to project failure if not taken seriously [17]. The CSFs approach is, thus, a trial to separate important areas that are crucial for managing projects to attain success [18].

As previously mentioned, the aim of this research is to explore CSFs essential for the success and of PPP educational projects in Egypt. Since these projects are in their early stages, it is difficult to study factors that are linked to the success of different stages of implementation and operation of PPP projects. Consequently, factors such as client brief/outcome, teamwork, delivery of assets and investment growth [19] were excluded from this research, while factors that are responsible for creating the environment necessary for PPP projects success and sustainability were reviewed. Undertaking this form of analysis may allow the different stakeholders in a PPP project in education in Egypt to understand the "big picture" of the operation environment, and the opportunities and threats that lie within it. Therefore, they can take advantage of the opportunities and minimize the threats. Factors responsible for creating the environment necessary for PPP projects success and sustainability can be grouped into four groups: political, legal, economic and financial as well as managerial and operational. This is discussed in the following points.

\subsubsection{Political Factors}

A strong political will from the government can only encourage the establishment of PPP projects by reducing resistance and providing a clear indicator of the intention of the government to commit to its contractual obligations. The two CSFs of this component are: (i) political support, and (ii) centralized system for managing PPP [20].

- Political Support: 
The political setting of the host country has a direct relation with PPP as a public policy [21]. This is because without the required political support no consent is awarded for public expenditure and work on public projects [20], and thus this factor is introduced as critical to the establishment and success of PPP. Furthermore, in states where political support is weak, many investors consider the political risk to be high and this restricts the number of competitors in the tendering process [22]. It is also highlighted that of crucial importance are the presence and constant revision of an explicit adopted policy document on PPP, and a clear program for distinct PPP projects. Furthermore, precise and explicit political support for PPP stated by major political parties with some stability over time is necessary [23]. It can be concluded from what has been mentioned that the existence of an explicit policy document on PPP and a clear program for distinct PPP projects is essential for PPP successful implementation.

- Centralized system for managing PPP:

The United Nations Economic and Social Council identified the need for an authoritative, central government commitment as one of the main ingredients of successful PPP programs. The report stated that the creation of PPP units is the best manifestation of this commitment. This unit is responsible for driving forward PPP projects, providing suitable advice, acting as a point of contact for prospective bidders and becoming a repository for knowledge and experience for PPP within the country. Moreover, a PPP unit can help in addressing limitations of capacity within government and contribute to quality control.

To sum up, the presence of a competent central unit that has the technical competence to put suitable procedures for PPP appraisal and prioritization and implementation is an important factor. Moreover, forming standardized PPP contracts is essential for adopting PPP projects. The previously discussed points lead to the first research hypothesis:

Hypothesis 1 (H1). The existence of favorable, supporting political factors is positively related to PPP success in the educational sector in Egypt.

\subsubsection{Legal Factors}

The eagerness of the private sector to contribute in developing infrastructure projects is influenced greatly by the legal environment in which projects operate. Laws grant security to private partners for protecting their interests and reducing risk [24]. However, having a complete and sound legal framework is not enough; it has to be a favorable legal framework. A favorable legal framework permits the development of a PPP project without unnecessary legal constraints on the engagement of the private sector [21]. Moreover, disputes are likely to occur and service delivery is likely to be delayed and/or impaired. Therefore, the presence of a functioning legal and regulatory framework reduces opportunistic inclinations, adjusts the interest of partners and provides confidence to the private partners, as it prevents political interference from government agencies [25].

Furthermore, the existence of alternative ways for resolving disputes is key to encouraging private and long-term investors. Equally, it is necessary that PPP should face "non-discriminatory taxation and regulation regimes" [26]. Finally, the presence of a favorable legal and regulatory framework and the existence of alternative dispute resolution systems as arbitration may be a critical factor for fostering partnership between public and private sectors. The discussion of the previous points leads to the second research hypothesis:

Hypothesis 2 (H2). The availability of a favorable legal and regulatory framework is positively related to PPP success in the education sector in Egypt.

\subsubsection{Economic and Financial Factors}

A PPP project attracts investments, if it is sustainable, financially applicable, and profitable. Therefore, to establish PPP in an economy, a market must exist in a way that permits PPP projects to 
make profits, the private sector has the intention to participate, and the financial market has the will to invest.

Thus, this component has three CSFs: (i) stable macroeconomic conditions, (ii) sound economic policy and (ii) available financial markets.

- Stable macroeconomic conditions:

Stable macroeconomic conditions is the keystone for any successful effort to increase private sector development and economic growth [27]. The indicators of macroeconomic stability are; low and stable inflation, low budget and current account deficits, stable and predictable exchange rate, low real interest rates, and comfortable foreign exchange reserves. The absence of a stable macroeconomic environment hinders domestic and foreign investments [28]. Therefore, the desire of private investments to cooperate in PPP infrastructure projects depends mainly on the operational environment of these projects [27].

- Sound economic policy:

The economic conditions have to be favorable for a financial transaction to be successful [21]. This can be stimulated to a certain extent through sound economic policy as investors are more expected to consider participating in a market where economic conditions allow for higher certainty. Moreover, private sector firms are unlikely to commit capital within countries where there is uncertainty over economic conditions, particularly repayment of sovereign debts. The favorable economic conditions lie largely outside the control of PPP stakeholders [24]. However, they are crucial to the growth of any PPP program. Consequently, governments should adopt economic policies that support economic stability and growth required for the private sector to operate with confidence [28].

- Available financial markets:

In the majority of PPP projects, most stakeholders cannot tolerate unnecessary or extra risks. Therefore, the financial markets nature is crucial in facilitating PPP projects, and unattractive financial markets that are politically unstable or adopt high interest rates, are sometimes a barrier to the success of a PPP [28]. Many other researchers argue that project financing is an essential factor for encouraging the private sector to invest in public infrastructure projects [21]. They attested to the fact that the existence of an effective financial market that has low financing costs and different categories of financial products would encourage the private sector to enter into PPP arrangements.

This means there are three important factors that are crucial for the success of PPP projects. First, the existence of macroeconomic conditions that lead to a stable exchange rate as well as low interest and inflation rates; second, the presence of sound economic policy that leads to economic growth, full employment and price stability; finally, the existence of effective financial markets and availability of flexible and attractive financial instruments are essential for PPP success. These intricacies are summarized in the third research hypothesis:

Hypothesis 3 (H3). The availability of economic and financial factors is positively related to PPP success in the educational sector in Egypt.

\subsubsection{Managerial and Operational Factors}

By managerial and operating factors, the researcher means the favorable and supporting factors, which affect PPP project management and operation directly. This includes the following CSFs: transparency in the procurement process, competitive procurement process, project technical feasibility, strong private consortium, appropriate risk allocation, shared authority, thorough and realistic assessment of costs and benefits, good governance and public/community support.

- Transparency in the procurement process:

Transparency refers to the way in which the design and initiation of projects, procurement and selection process have to be organized [29]. Thus, transparency depends on cordial and continuous communication between partners and external stakeholders [21]. Consequently, partners should consult each other for any interpretation concerning the agreement. Similarly, both public and private partners should communicate with external stakeholders or users of the project in a transparent and 
open way. Moreover, the government has to clear constantly any doubts or rumors that appear publicly concerning the delivery of PPP projects, because negative public perception could have an impact on the success of the project implementation.

Finally, transparency guarantees that the project delivers the expected outcomes and quality services. To conclude, the presence of clear contractual obligations for accountability purposes as well as a proactive public disclosure process to curb corruption and fraud, i.e., to make the process open and public is essential to the PPP project's success.

- Competitive procurement process:

To guarantee the selection of a qualified concessionaire, any procurement model has to be established with essential elements such as, head-to-head competition, actual competitors' fair treatment, and a competition open to technological change [30]. To facilitate this competition, it is necessary to have enough potential bidders in the procurement process. Thus, it is crucial to protect the interests of private sector bidders and ensure that no preference is given to any party [16].

However, although the selection of the private investor through competition is often the preferred method, sometimes private companies advance to governments new project ideas, known as "unsolicited proposals" [28]. These proposals are usually controversial if governments conduct direct negotiation with the original proponent concerning the project contract without adequate transparent or competing proposals. To overcome such situations, governments should develop sufficient procedures that embody transparency and competition for proposing unsolicited proposals. The government, therefore, needs to develop a clear and effective policy on unsolicited proposals from the private sector.

Therefore, there are two critical factors for encouraging private investors to participate in PPP arrangements. First, the existence of procedures that guarantee participation of an ample number of capable bidders in the process. Second, developing a clear and effective policy for unsolicited proposals. - Project technical feasibility (technical knowledge and expertise):

A technical feasibility study usually determines the details of how one delivers a product or service. A project's technical feasibility usually considers the availability of required technology and resources, that is materials and labor. Thus, the technical aspects for developing a proposed PPP project have to be assessed to ascertain whether they are well within the project team's capabilities to produce such a product or service [21]. It has also to be noted that a PPP project is not considered attractive if the necessary requirements and technologies change continuously during the life of the project [20]. To overcome this problem, sufficient flexibility has to be embedded in the contract to face the continuous changes in a flexible way.

The public and private partners' experience in a PPP model is also crucial to success, especially when it has a complex and sensitive nature [20]. Furthermore, the possibility of introducing creative solutions is effective to achieve Value for Money (VFM) [31].

To conclude, the existence of clear procedures for making a decision requires feasibility studies that have a VFM analysis. Moreover, a Public Sector Comparator (PSC) assessment, and sustainability analysis to ensure that technical aspects are well within the project team's capabilities is a key factor for PPP success.

- Strong private consortium:

A responsible and organized private sector company is essential for a successful PPP project [22]. This is because PPP projects have a complex nature that makes it hard most of the time for an individual company to implement the project; thus, companies often unite to set a consortium. Thus, in contracting out PPP projects, it should be guaranteed that the private sector consortium parties are competent and have the financial ability to undertake the project.

Consequently, the selection of an appropriate concessionaire relates to the PPP project's implementation, which means that if a project has the right actors, who share common objectives, the project will probably be implemented successfully [21]. Finally, it can be concluded from what has been mentioned before that the selection of a strong private consortium is a crucial factor for PPP 
success. Furthermore, this consortium has to possess expertise, innovation and good reputation to guarantee success of the partnership.

- Appropriate risk allocation and risk sharing:

Risk allocation is a main component of any PPP [20]. There is argument about how much risk should be transferred from the public to the private sector partner. In general, the more risk transferred to the private sector partner, the more financial reward the private partner will claim. Moreover, one of the distinguishing features of a PPP is its high level of risk, which is principally due to the long term of the contract and the various participants included in the partnership [32]. Accordingly, achieving the best risk distribution should be undertaken using well-established rules [16]. These rules should stress that the risk is only given to those who are understand clearly the risks they are taking. That is, they are capable (including expertise and authority) of manage the risk in an effective and efficient manner; have the resources and capability to deal with the risk if it happens; and have the opportunity to charge a fair and appropriate premium for taking on the risk.

Accordingly, from what was mentioned previously, it could be concluded that the existence of procedures to ensure risk allocation between parties of PPP is an important factor for its success. Moreover, risks have to be transferred to the party capable of controlling them. Furthermore, risks that are considered out of the control of both public and private sectors have to be shared between them.

- Shared authority between public and private sector (trust and openness between parties):

Nelson and Zaldek [33] recommend that both public and private sectors should respect each other during the negotiations of the procurement process. Furthermore, discussing individual expectations and agendas with clarity and openness as well as balancing between desired participant benefits and societal benefits ensure a PPP's successful implementation. Therefore, it is necessary that the public and private sector work together, focus on the project outcomes rather than maximizing their own interests, and cooperate for mutually permanent value.

Therefore, negotiations during the procurement process should guarantee mutual respect and cooperation between the various participants in the partnership all over the stages of the project. This is a crucial factor for the success of the partnership and its sustainability.

- Thorough and realistic assessment of the costs and benefits (value for money):

PPPs should produce equivalent or better VFM than a pure public sector project approach. The VFM can be realized through risk transfer, innovation, better asset utilization and integrated whole-of-life management [34]. From this, it is concluded that resorting to PPP projects is justified only when such projects are economically superior to the traditional public procurement approach, which means that it should not give rise to costs that go beyond the associated benefits. Consequently, the presence of a process that assess PPP bids against the public sector comparator (PSC) to demonstrate VFM for a PPP project is of critical importance.

- Good governance:

Good governance in a PPP refers to a number of interlinked ingredients, such as public accountability, public management, sustainable development and dispute resolution [29]. Therefore, the government's irrelevant involvement or the government's incapability to run PPP projects may lead to failure of the project [33]. To administer the complex procedures and expected risks of PPP, governments should be clear, devoted, and technically capable of managing governance issues. Thus, good governance is crucial for managing PPP as this guarantees that the involvement of the private sector produces the maximum benefit for the public. To conclude, it is a necessity that the public sector possesses the capacity and knowledge to devise, implement and manage PPP agreements in the long run. This means that without this capacity the PPP project fails.

- Social support:

The support of society or the public community is essential for PPP projects. By public community, we mean the media, trade unions, civil society and other non-governmental organizations. This is supported by previous studies. For instance, Osei-Kyei and Chan [21] stated that public and community support at the beginning of the project help in eliminating any kind of delay such as that of land 
acquisition for project establishment. Moreover, it decreases the production cost because local people could be employed as workers. Furthermore, social acceptance nowadays is crucial, because citizens have expectations regarding the quality of the service, its environmental effect as well as the job opportunities a project would present. Therefore, public involvement makes them understand the possible impacts and benefits of a PPP project through certain procedures that ensure public awareness and education would be of significant importance. Thus, for PPP development, we propose the fourth research hypothesis:

Hypothesis 4 (H4). The existence of a favorable, supporting managerial and operating environment is positively related to PPP success in the educational sector in Egypt.

Finally, it could be concluded that the CSFs of PPP projects success in education in Egypt can be grouped into four groups with lists of sub-factors under each group. These four groups are: political, legal, economic and financial, as well as managerial and operating. Consequently, a conceptual framework has been formed and adopted by this research study in Figure 1.

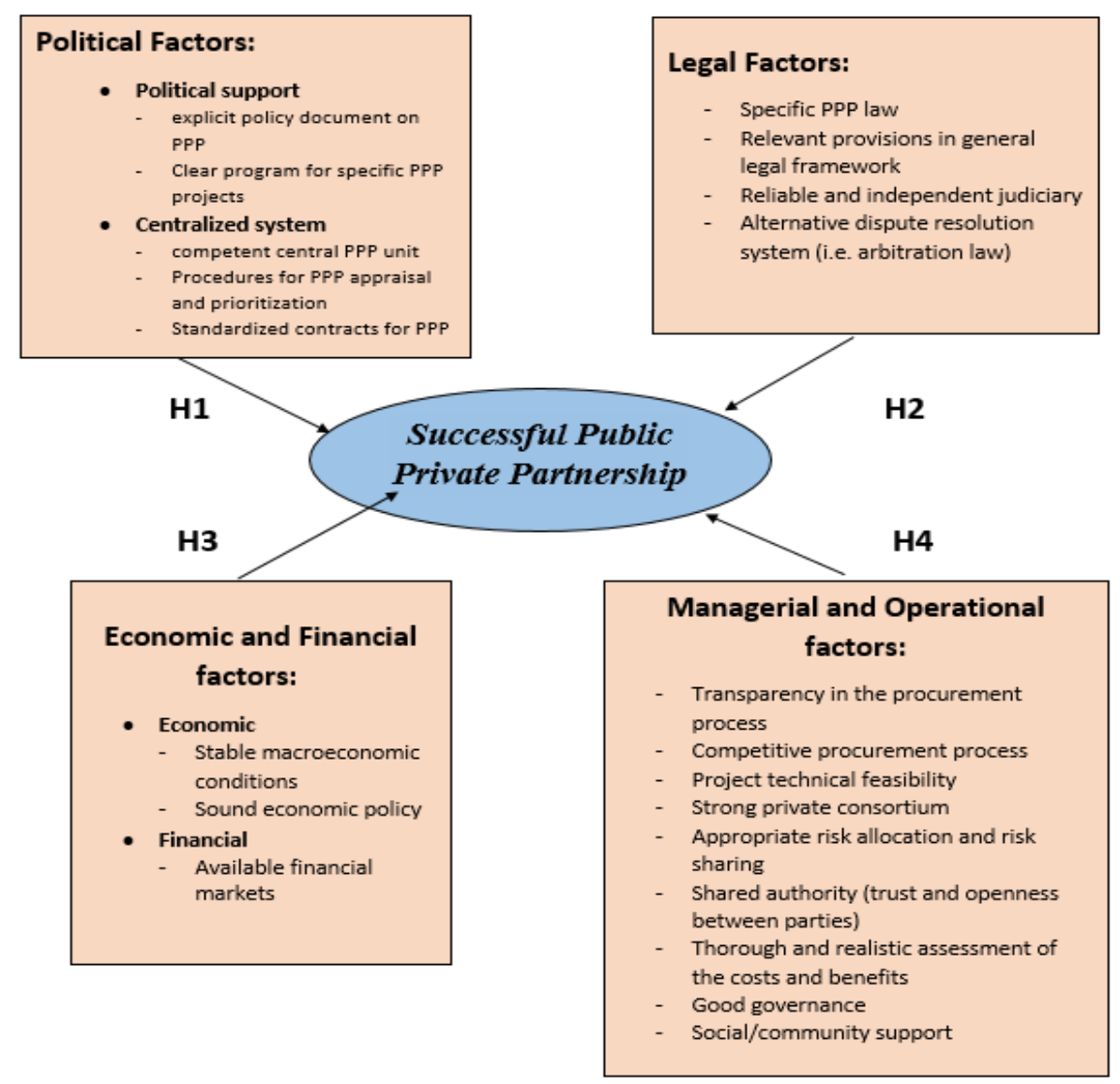

Figure 1. Research conceptual framework.

\section{Research Methodology}

According to Saunders et al., [35] exploratory research is undertaken when there are few or no earlier studies concerning a specific issue or problem to refer to. Consequently, this research project is exploratory in nature since there are few or no earlier studies conducted on this topic. Moreover, PPP education projects in Egypt are in their nascent stages, thus, it is difficult to collect and analyze data from them.

As for the population and sample of the study, there is no known register of PPP projects or practitioners in Egypt. Consequently, there is no way of knowing the precise extent of the population 
from which the sample of the study would have to be drawn. This means that there is no accessible sampling frame for the population from which the sample is to be taken, and the difficulty of creating such a sampling frame means that the snowball sampling approach is the only feasible one [36]. As a result, the target sample for this research project was selected using snowball sampling [37].

Consequently, an exploratory sequential mixed method research (MMR) design was selected in order to broadly explore and understand the CSFs of PPP projects in education in Egypt. The research process involved the following phases: first, a literature review was undertaken to identify what variables to consider in the research. It outlines the previous research and the CSFs identified by them for the successful implementation of PPPs. Second, interviews were mainly held with experts in education in Egypt to obtain data from their point of view.

Twenty one CSFs contributing to the success of PPP projects were first identified by reviewing previous studies and literature on this subject. Then, a qualitative study was held via expert interviews. Consequently, 13 face-to-face interviews were conducted with experts and professionals in the education industry as illustrated in Table 1; they were Egyptian experts who have participated in PPP education projects or have a valuable experience of it. Moreover, two of these interviews were held with two British experts (for their rich experience in PPP projects in the education field in the UK, in addition, to their knowledge of developing countries' environments). Most of these experts have overall experience in PPP education projects ranging from 5 to 15 years. It is worth mentioning that most of these PPP were on the educational program level.

Table 1. Qualitative data expert profile respondents.

\begin{tabular}{clcc}
\hline & \multicolumn{1}{c}{ Position } & Sector & Experience (years) \\
\hline 1 & Member of House of Lords-Global Partners & Developer & 15 \\
\hline 3 & Professor of Law at Lister University-Global Partners & Developer & - \\
\hline 4 & Prof. of Engineer and Former Minister of Higher Education & Public & 15 \\
\hline 5 & $\begin{array}{l}\text { Prof. of Engineer and Former Minister of Higher Education } \\
\text { Commerce- Alexandria University }\end{array}$ & Public & 15 \\
\hline 6 & $\begin{array}{l}\text { Prof. of Agricultural Engineering and Former Dean of Faculty } \\
\text { of Agriculture-Ain Shams University }\end{array}$ & Public & 15 \\
\hline 7 & $\begin{array}{l}\text { Prof. of Tourism and Former Dean of Faculty of } \\
\text { Tourism-Helwan University }\end{array}$ & Public & 15 \\
\hline 8 & CSR director of Americana Group Egypt & Private & 15 \\
\hline 9 & JCA & Developer & 3 \\
\hline 10 & Former director of education Sector in Misr EL kheir & Developer & 5 \\
\hline 11 & Dean of Faculty of Management-AASTMT & Private & - \\
\hline 12 & $\begin{array}{l}\text { Prof. of Literature and Criticism-Agent of Egyptian Scholars } \\
\text { Association Founders }\end{array}$ & Public & - \\
\hline 13 & President of Future University & Private & - \\
\hline
\end{tabular}

The interview questions were structured in two sections. Section 1 focused on factors that lead to the resort to PPP in education in Egypt, barriers to their implementation, what a successful PPP project is and the interviewees' experience in PPP in education. In Section 2, questions are mainly open-ended that focus on discussing the CSFs for PPP implementation in education in Egypt. Then, interviews were analyzed using thematic and content analyses with extracted codes from NVIVO software, which is designed to analyze qualitative data.

Based on the outcome of the expert review, a questionnaire was constructed to confirm the reviewed framework and generalize from the whole population sample. Prior to distribution, a peer review of the questionnaire was conducted. Two PPP central unit staff (financial analyst and operational manager), 
two professors at the Faculty of Tourism, Helwan University, and a training manager in the VSE corporation, were requested by the researcher to answer the preliminary questionnaire. The objective of this review was to ensure content validity and reliability of the questionnaire. There were no adverse comments proposed, however, one of the comments was that some of the proposed factors are logically important for any PPP project not only that of education projects. Another comment is that the questionnaire needs more details to be understood easily to a wider range of people especially those who are not acquainted with some of the technical terms used. Consequently, the 21 CSFs, shown in Table 2, contained in the questionnaire's first version were included in the final version of the questionnaire but in detail, i.e., factor operationalization was used to explain each factor. It is worth mentioning that factors operationalization were obtained and were developed based on items from the literature and expert opinions were also included (Table 3).

Table 2. Critical success factors.

\begin{tabular}{|c|c|c|c|}
\hline No. & Category & CSF & CSF Code \\
\hline \multirow{5}{*}{1.} & \multirow{5}{*}{ Political Factors } & 1. Existence of explicit policy document on PPP & P1 \\
\hline & & 2. Existence of Clear program for specific PPP projects & $\mathrm{P} 2$ \\
\hline & & 3. Existence of a competent central PPP unit & P3 \\
\hline & & 4. Existence of Procedures for PPP appraisal and prioritization & $\mathrm{P} 4$ \\
\hline & & $\begin{array}{l}\text { 5. Existence of Standardized contracts for PPP and/or } \\
\text { processes for implementation }\end{array}$ & P5 \\
\hline \multirow{4}{*}{2.} & \multirow{4}{*}{ Legal Factors } & 6. Existence of Specific PPP law & L1 \\
\hline & & $\begin{array}{l}\text { 7. Existence of Relevant provisions related to PPP in the } \\
\text { general legal framework including procurement law }\end{array}$ & L2 \\
\hline & & 8. Existence of Reliable and independent judiciary & L3 \\
\hline & & $\begin{array}{l}\text { 9. Existence of Alternative dispute resolution system (i.e., } \\
\text { arbitration law) }\end{array}$ & L4 \\
\hline \multirow{3}{*}{3.} & \multirow{3}{*}{$\begin{array}{l}\text { Financial and Economic } \\
\text { Factors }\end{array}$} & 10. Stable macroeconomic conditions & $\mathrm{F} 1$ \\
\hline & & 11. Sound economic policy & F2 \\
\hline & & 12. Available financial markets & F3 \\
\hline \multirow{9}{*}{4.} & \multirow{9}{*}{$\begin{array}{l}\text { Managerial and } \\
\text { Operational Factors }\end{array}$} & 13. Transparency in the procurement process & M1 \\
\hline & & 14. Competitive procurement process & M2 \\
\hline & & 15. Project technical feasibility (technical competence) & M3 \\
\hline & & 16. Strong private consortium & M4 \\
\hline & & 17. Appropriate risk allocation and risk sharing & M5 \\
\hline & & $\begin{array}{l}\text { 18. Shared authority between public and private sectors (trust } \\
\text { and openness between parties) }\end{array}$ & M6 \\
\hline & & 19. Thorough and realistic assessment of the costs and benefits & M7 \\
\hline & & 20. Good governance & M8 \\
\hline & & 21. Social support & M9 \\
\hline
\end{tabular}


Table 3. Operationalization of variables.

\begin{tabular}{|c|c|c|}
\hline CSFs & Operationalization/Measurement & Authors \\
\hline \multicolumn{3}{|c|}{ Political factors: } \\
\hline Political support & $\begin{array}{l}\text { Existence of: } \\
-\quad \text { Explicit policy document on PPP } \\
-\quad \text { Clear program for specific PPP projects }\end{array}$ & $\begin{array}{l}\text { Li et al., } 2005 \text { [31]; Hardcastle et al., } 2005 \text { [22]; Kwak et al., } 2009 \\
\text { [16]; Diba, } 2012 \text { [27]; Yang et al., } 2013 \text { [38]; Verhoest et al., } 2015 \\
\text { [39]; OECD, } 2008 \text { [40]; Baxter, } 2017 \text { [41]. }\end{array}$ \\
\hline Centralized system for managing PPP & $\begin{array}{ll}\text { Existence of: } \\
-\quad \text { A competent central PPP unit } \\
-\quad \text { Procedures for PPP appraisal and prioritization } \\
-\quad \text { Standardized contracts for PPP and/or processes } \\
\quad \text { for implementation }\end{array}$ & $\begin{array}{l}\text { UNESCO, } 2002 \text { [42]; Jamali, } 2004 \text { [23]; Li et al., } 2005 \text { [31]; Ong'olo } \\
\text { 2006 [28]; Zhang, } 2005 \text { [30]; Diba, } 2012 \text { [27]; Verhoest, et al., } 2015 \\
\text { [39]; Ossman, } 2019 \text { [43]; Muhammad and Gohar, } 2019 \text { [44]. }\end{array}$ \\
\hline \multicolumn{3}{|c|}{ Legal factors: } \\
\hline Favorable legal and regulatory framework & $\begin{array}{ll}\text { Existence of: } \\
-\quad \text { Specific PPP law } \\
-\quad \text { Relevant provisions related to PPP in the general legal } \\
\text { framework including procurement law } \\
-\quad \text { Reliable and independent judiciary } \\
-\quad \text { Alternative dispute resolution system (i.e., arbitration law) }\end{array}$ & $\begin{array}{l}\text { Pongsiri, } 2002 \text { [24]; Jamali, } 2004 \text { [23]; Grimsey and Lewis } 2004 \\
\text { [45]; Li et al., 2005 [31]; Zhang, } 2005 \text { [30]; Yang et al., } 2013 \text { [38]; } \\
\text { Verhoest, et al., } 2015 \text { [39]; Kang et al., } 2018 \text { [46] }\end{array}$ \\
\hline \multicolumn{3}{|c|}{ Economic and financial factors } \\
\hline Stable macroeconomic conditions & $\begin{array}{ll}\text { Existence of macroeconomic conditions that leads to: } \\
-\quad \text { Stable exchange rate } \\
-\quad \text { Low interest rate } \\
-\quad \text { Low inflation rate } \\
\end{array}$ & $\begin{array}{l}\text { Hammami et al., } 2006 \text { [47]; Khan, } 2009 \text { [26]; Diba, } 2012 \text { [27]; } \\
\text { Muhammed and Gohar, } 2019 \text { [44]. }\end{array}$ \\
\hline Sound economic policy & $\begin{array}{l}\text { - Presence of policy that leads to: economic growth, full } \\
\text { employment and price stability }\end{array}$ & $\begin{array}{l}\text { European Investment Bank, } 2000 \text { [48]; Li et al., } 2005 \text { [31]; Diba, } \\
2012 \text { [27]. }\end{array}$ \\
\hline Available financial markets & $\begin{array}{l}\text { - Existence of effective financial markets (Stock exchange, } \\
\text { banks, insurance companies and pension funds) } \\
\text { Availability of flexible and attractive financial instruments, } \\
\text { such as debt, equity, supplier and purchaser credit, } \\
\text { and securities }\end{array}$ & $\begin{array}{l}\text { Jefferies et al., } 2002 \text { [18]; Grimsey and Lewis, } 2004 \text { [45]; Li et al., } \\
2005 \text { [31]; Zhang, 2005 [30]; Chan et al., 2010 [49]; Diba, } 2012 \text { [27]; } \\
\text { Yang et al., } 2013 \text { [38]; Kang et al., } 2018 \text { [46]; Ossman, } 2019 \text { [43]. }\end{array}$ \\
\hline \multicolumn{3}{|c|}{ Managerial and operational factors: } \\
\hline Transparency in the procurement process & $\begin{array}{l}\text { Presence of: } \\
-\quad \text { Clear contractual obligations for accountability purposes } \\
-\quad \text { Proactive public disclosure process to curb corruption and } \\
\text { fraud (process is made open and public) }\end{array}$ & $\begin{array}{l}\text { Li et al., } 2005 \text { [31]; Chan et al., } 2010 \text { [49]; Helmy, } 2011 \text { [50]; } \\
\text { Babatunde et al., } 2012 \text { [51]; Diba, } 2012 \text { [27]; Osei-Kyei and Chan, } \\
2015 \text { [21]. }\end{array}$ \\
\hline
\end{tabular}


Table 3. Cont

\begin{tabular}{|c|c|c|}
\hline CSFs & Operationalization/Measurement & Authors \\
\hline Competitive procurement process & 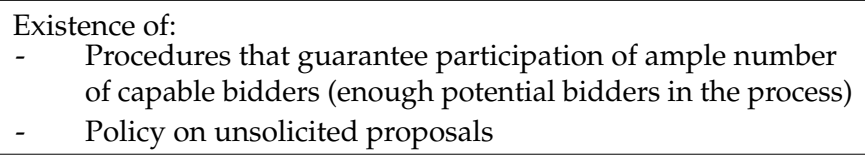 & $\begin{array}{l}\text { Hardcastle et al., } 2005 \text { [22]; Cangiano et al., } 2006 \text { [52]; Chan et al., } \\
2010 \text { [49]; Diba, } 2012 \text { [27]; Li and Akintoye (2003) [53]. }\end{array}$ \\
\hline $\begin{array}{l}\text { Project technical feasibility (technical } \\
\text { competence) }\end{array}$ & $\begin{array}{l}\text { Existence of procedures to ensure that Technical aspects are } \\
\text { well within the project team's capabilities (can it actually be } \\
\text { implemented?) }\end{array}$ & $\begin{array}{l}\text { Jefferies, } 2002 \text { [18]; Zhang, } 2005 \text { [30]; Chan et al., } 2010 \text { [49]; } \\
\text { Yitmen et al., 2018 [19] }\end{array}$ \\
\hline Strong private consortium & Expertise, innovation and good reputation & $\begin{array}{l}\text { Zhang, } 2005 \text { [30]; Chan et al., } 2010 \text { [49]; Osei-Kyei and Chan, } 2015 \\
\text { [21]; Muhammad and Gohar, } 2019 \text { [44]. }\end{array}$ \\
\hline Appropriate risk allocation and risk sharing & $\begin{array}{l}\text { Existence of procedures to ensure that: } \\
\text { - } \quad \text { Risk is allocated to the party that has more control over it } \\
\text { - } \quad \text { Risks that are beyond the control of both public and private } \\
\text { sectors is shared }\end{array}$ & $\begin{array}{l}\text { Li et al., } 2005 \text { [31]; Zhang, } 2005 \text { [30]; Kwak et al., } 2009 \text { [16]; Chan } \\
\text { et al., } 2010 \text { [49]; Diba, } 2012 \text { [27]; Yitmen et al., } 2018 \text { [19]; } \\
\text { Muhammed and Gohar, } 2019 \text { [44]. }\end{array}$ \\
\hline $\begin{array}{l}\text { Shared authority between public and private } \\
\text { sectors (trust and openness between parties) }\end{array}$ & $\begin{array}{l}\text { Negotiations during the procurement process should } \\
\text { guarantee mutual respect and cooperation }\end{array}$ & $\begin{array}{l}\text { Jamali, } 2004 \text { [23]; Li et al., } 2005 \text { [31]; Kang et al., } 2018 \text { [46]; } \\
\text { Muhammad and Gohar, } 2019 \text { [44]. }\end{array}$ \\
\hline $\begin{array}{l}\text { Thorough and realistic assessment of the } \\
\text { costs and benefits }\end{array}$ & $\begin{array}{l}\text { - Existence of process that assess PPP bids against the public } \\
\text { sector comparator (PSC) to demonstrate VFM for the } \\
\text { PPP project }\end{array}$ & $\begin{array}{l}\text { Li and Akintoye, 2003 [53]; Zhang, } 2005 \text { [30]; Li et al., } 2005 \text { [31]; } \\
\text { Sarmento, } 2010 \text { [54]; Chan et al., } 2010 \text { [49]; Diba, } 2012 \text { [27]. }\end{array}$ \\
\hline Good governance & $\begin{array}{l}\text { Public sector capacity and knowledge to devise, implement } \\
\text { and manage PPP contractual relationships over the } \\
\text { long run }\end{array}$ & $\begin{array}{l}\text { Ong'olo, } 2006 \text { [28]; Cesar and Ada, } 2008 \text { [55]; Kwak et al., } 2009 \\
\text { [16]; Chan et al., } 2010 \text { [49]; Helmy, } 2011 \text { [50]; Diba, } 2012 \text { [27]. }\end{array}$ \\
\hline Social support & $\begin{array}{l}\text { Presence of procedures that ensures public awareness and } \\
\text { education of the necessity of project }\end{array}$ & $\begin{array}{l}\text { Li et al., } 2005 \text { [31]; Yong, 2010; Ng et al., 2010; OECD, 2010; Diba, } \\
2012 \text { [27]; Osei-Kyei and Chan, } 2015 \text { [21]; Yitmen et al., 2018 [19] }\end{array}$ \\
\hline \multicolumn{3}{|c|}{ Dependent variable: } \\
\hline $\begin{array}{l}\text { Successful PPP project in education } \\
-\quad \text { Within cost estimated } \\
-\quad \text { Within scope designed } \\
\text { - } \quad \text { At the desired performance or } \\
\text { specified level of performance } \\
\text { - Quality of outcome is accepted by } \\
\text { the customer }\end{array}$ & $\begin{array}{l}\text { Output specification and performance standards that are: } \\
\text { - } \quad \text { Measurable in quantitative and qualitative terms } \\
\text { - } \quad \text { Verifiable by third parties like courts and arbitrators }\end{array}$ & Diba, 2012 [27]; Kwofie et al., 2016 [37]. \\
\hline
\end{tabular}


Since there is no limitation for the population of the study, the questionnaire was distributed among 300 respondents as the minimum sample size calculated as the multiplication of number of questions in a questionnaire by $10(21 \times 10=210)$ according to Saunders et al. [35]. These 300 respondents are members in institutions that have taken part in PPP projects or have an adequate knowledge of its development. The questionnaire was sent to non-profit organizations (e.g., Misr Elkheir, Japan International Cooperation Agency (JICA), and German Cooperation), private sector (e.g., Americana group, Arab Academy for Science and Technology and Maritime Transport (AASTMT), Tanta Motors, Shoura, Burger King, Macmillan Education, Springer Nature, Etisalat Misr, Edugate, Alex book Center) public sector (e.g., Ministry of Finance, Alexandria University, Helwan University, Ain Shams University, Ministry of high Education) and existing PPP projects (e.g., Japanese Egyptian Schools). Then, after excluding unanswered questionnaires and invalid answers, the sample size became 206 respondents.

The identified questionnaire respondents were then requested to rate the CSFs according to their level of agreement. They were given the option to answer the questionnaire in a soft copy that was included in an email, online google form or simply to complete a hard copy, to be easily accessible for the targeted population to respond and send back to the researcher. The questionnaire was developed based on two sections: general experience of respondents in PPP projects and CSFs of PPP in education in Egypt. The first set of questions was multiple choice, whereas the second set was based on a 5-point Likert scale with ' 1 ' representing least important, ' 2 ' unimportant, ' 3 ' important, ' 4 ' very important and ' 5 ' neutral (selected when the respondent is uncertain about the rating of a particular statement).

Finally, data collected were analyzed to identify the CSFs for PPP implementation in the education sector in Egypt. In the questionnaire analysis, descriptive statistics, reliability, factor analysis, correlation, and structural equation modeling (SEM) tools were utilized to justify the proposed research model using SPSS and AMOS program.

\section{Results and Analysis}

This section introduces the outcome of both qualitative and quantitative data analysis carried out on data gathered and are presented to confirm or reject the role of proposed CSFs in PPP projects in the Egyptian educational sector.

\subsection{Interviews Analysis}

The current research fills the gap in literature and develops insights into understanding the critical success factor, in other words the factors that help the success of PPP. This happens by conducting an interview with open-ended structured questions to best answer the researcher's questions and fulfill the research objectives. The researcher aimed to guarantee that the sample of the study was representative of all sectors that would participate in PPP projects, i.e., public sector, private sector and development partner. Since the participants were all senior figures, the interviews were held in the interviewees' offices in Cairo and Alexandria and were designed to last from 20 to $30 \mathrm{~min}$. Themes are recognized from the answers according to the repeated words and ideas. The interviews are analyzed using thematic and content analyses with extracted codes from NVIVO software, which is designed to analyze qualitative data.

Using thematic analysis, the interviews collected were analyzed and the respondents' answers were investigated. Throughout the answers of the interviewees, the researcher evaluates the responses in the interview to be able to obtain the main themes that could be extracted for this research. Open questions were posed to understand the factors that help the success of the partnership between the public sector and the private sector in Egypt especially in the educational sector. Scanning the responses, the researcher observed that the answers of the interviewees are diversified into mainly four aspects, political aspect, legal aspect, economic and financial aspect and managerial and operational aspect.

Here is a quote which illustrates the economic and financial aspect: "The first thing we give is the job opportunities for the people who are most in need, life has become difficult, the Egyptian people 
are not able to meet their needs. Therefore, we help the student to rely on himself from the first day of studying instead of relying on his parents throughout the four years of studying. Now from the first day, the college and the company spend about 1500 to 2000 pounds as a monthly salary on him with incentives and all needs".

Others mention the political aspect: "You treat the issue as if it were a general trend. This is a policy and two policies exist. Consequently, there are two different paths and not a general path. This means that if we talk about the Ministry of Education, it runs the partnerships schools at the same time, the state run the second track, i.e., public schools, each one of them has its goal and each deals with a class".

Others mention managerial and operational aspects like: "There are many reasons related to financing, budget deficit, and efficiency reasons because private sector participation gives some type of efficiency in resource management because it is managed according to economic foundations". Others mentioned the legal aspect as: "You need to have a legislation, which effectively ensures that the process of the contract word is fair. That there is monitoring for the process throughout".

Using content analysis, data obtained from the 13 interviewees were analyzed to extract the word frequency table, word cloud and tree mapping using NVIVO program for qualitative analysis. The word cloud is shown in Figure 2. These words extracted are considered as codes that the researcher has to rely on to form the categories and themes by gathering similar concepts together.

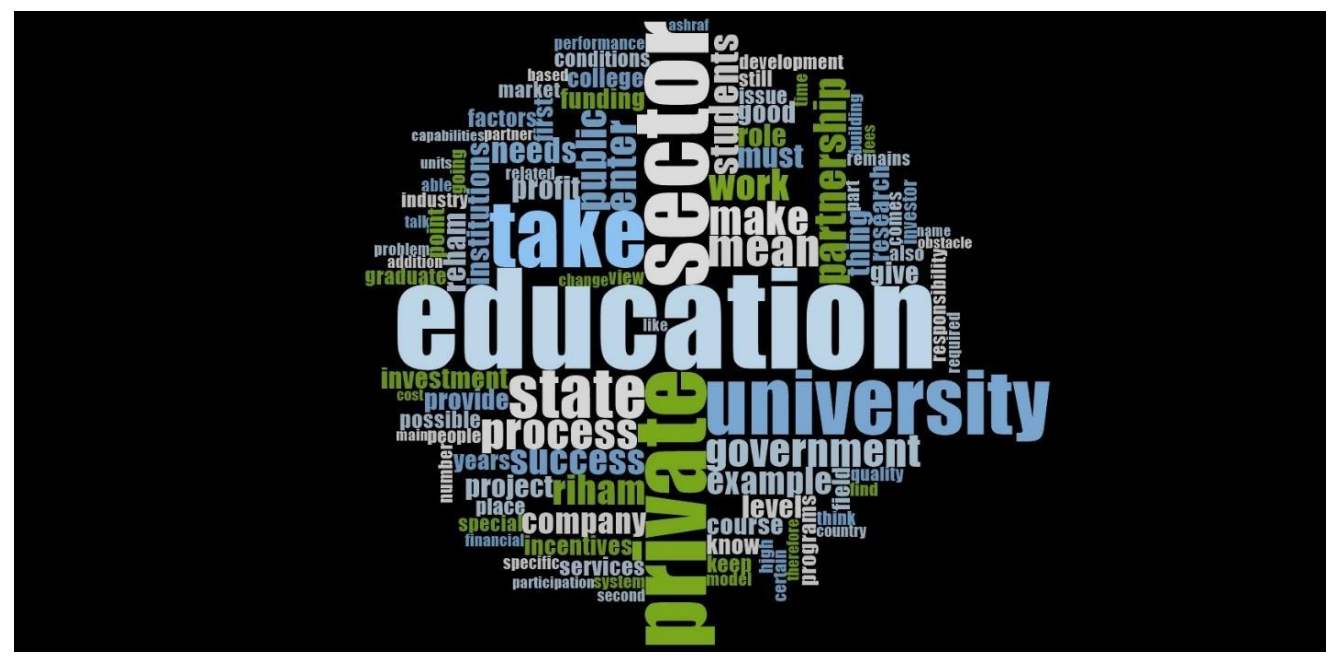

Figure 2. Word Cloud.

Through the following subsections, the researcher tries to relate and identify the codes obtained by the word frequency table to certain categories and themes to be able to extract and find out the main themes and concepts revealed by the interviewees.

\subsubsection{Theme of Managerial and Operational Factor}

A theme of "Managerial and Operational Factor" was observed by the researcher when merging the categories of infrastructure and obligation. The category "infrastructure" includes codes: sector, government, company, institutions while the category "management" includes codes: education, private, state, success, public, role and responsibility, as illustrated in the Table 4 below.

\subsubsection{Theme of Economic and Financial Factors}

A theme of "Economic and Financial Factors" was observed by the researcher when merging categories of "Economic" and "Finance". The category "Economic" was observed by having codes of needs, factors, market, programs, industry and development, while the codes of investment, project, funding, investor and financial are merged in a category of "Finance" as shown in Table 5 below. 
Table 4. Word frequencies for managerial and operational factor theme.

\begin{tabular}{|c|c|c|c|c|c|c|}
\hline Themes & Categories & Codes & Length & Count & $\begin{array}{c}\text { Weighted } \\
\text { Percentage (\%) }\end{array}$ & Total \\
\hline \multirow{19}{*}{$\begin{array}{l}\text { Managerial and } \\
\text { Operational Factor }\end{array}$} & \multirow{9}{*}{ Infrastructure } & Sector & 6 & 197 & 2.35 & \multirow{19}{*}{17.51} \\
\hline & & Government & 10 & 130 & 0.93 & \\
\hline & & Company & 7 & 60 & 0.68 & \\
\hline & & Institutions & 12 & 69 & 0.60 & \\
\hline & & Building & 8 & 65 & 0.28 & \\
\hline & & Country & 7 & 46 & 0.24 & \\
\hline & & Entity & 6 & 17 & 0.20 & \\
\hline & & Ministry & 8 & 17 & 0.20 & \\
\hline & & Egypt & 5 & 15 & 0.18 & \\
\hline & \multirow{10}{*}{ Management } & Education & 9 & 295 & 3.10 & \\
\hline & & Private & 7 & 219 & 2.24 & \\
\hline & & University & 10 & 184 & 1.93 & \\
\hline & & State & 5 & 161 & 1.51 & \\
\hline & & Public & 6 & 90 & 0.83 & \\
\hline & & Success & 7 & 86 & 0.83 & \\
\hline & & Role & 4 & 70 & 0.58 & \\
\hline & & Responsibility & 14 & 34 & 0.34 & \\
\hline & & System & 6 & 44 & 0.28 & \\
\hline & & Management & 10 & 42 & 0.21 & \\
\hline
\end{tabular}

Table 5. Word frequencies for economic and financial factors theme.

\begin{tabular}{|c|c|c|c|c|c|c|}
\hline Themes & Categories & Codes & Length & Count & $\begin{array}{c}\text { Weighted } \\
\text { Percentage (\%) }\end{array}$ & Total \\
\hline \multirow{14}{*}{$\begin{array}{l}\text { Economic and } \\
\text { Financial Factors }\end{array}$} & \multirow{6}{*}{ Economic } & Needs & 5 & 145 & 0.70 & \multirow{14}{*}{5.82} \\
\hline & & Factors & 7 & 42 & 0.43 & \\
\hline & & Market & 6 & 32 & 0.38 & \\
\hline & & Programs & 8 & 38 & 0.41 & \\
\hline & & Industry & 8 & 28 & 0.33 & \\
\hline & & Development & 11 & 58 & 0.33 & \\
\hline & \multirow{8}{*}{ Finance } & Investment & 10 & 64 & 0.53 & \\
\hline & & Project & 7 & 69 & 0.60 & \\
\hline & & Funding & 7 & 56 & 0.51 & \\
\hline & & Investor & 8 & 27 & 0.32 & \\
\hline & & Financial & 9 & 21 & 0.25 & \\
\hline & & Fees & 4 & 21 & 0.25 & \\
\hline & & Profit & 7 & 69 & 0.58 & \\
\hline & & Money & 5 & 18 & 0.20 & \\
\hline
\end{tabular}




\subsubsection{Theme of Legal Factors}

Another theme that was observed by the researcher was the theme of "legal factors". This theme was observed by merging categories of "obligation" and "rules". The category "obligation" includes codes: must, possible, know, incentives, field and issue. While, the category "rules" includes codes: required, able, obstacles, capabilities, eligibility, control and conditions as shown in Table 6 below.

Table 6. Word frequencies for legal factors theme.

\begin{tabular}{|c|c|c|c|c|c|c|}
\hline Themes & Categories & Codes & Length & Count & $\begin{array}{c}\text { Weighted } \\
\text { Percentage }(\%)\end{array}$ & Total \\
\hline \multirow{13}{*}{ Legal Factors } & \multirow{6}{*}{ Obligation } & Must & 4 & 54 & 0.64 & \multirow{13}{*}{4.7} \\
\hline & & Possible & 8 & 44 & 0.42 & \\
\hline & & Know & 4 & 56 & 0.47 & \\
\hline & & Incentives & 10 & 43 & 0.47 & \\
\hline & & Field & 5 & 76 & 0.42 & \\
\hline & & Issue & 5 & 92 & 0.39 & \\
\hline & \multirow{7}{*}{ Rules } & Required & 8 & 54 & 0.27 & \\
\hline & & Able & 4 & 30 & 0.27 & \\
\hline & & Obstacles & 8 & 19 & 0.23 & \\
\hline & & Capabilities & 12 & 44 & 0.22 & \\
\hline & & Eligibilities & 11 & 18 & 0.21 & \\
\hline & & Control & 7 & 52 & 0.19 & \\
\hline & & Conditions & 10 & 61 & 0.39 & \\
\hline
\end{tabular}

\subsubsection{Theme of Political Factors}

A theme of "Political Factors" was observed by the researcher, which include the category "design", this category was observed by having codes of process, take, partnership, work, level, high as illustrated in Table 7 below.

Table 7. Word frequencies for political factors theme.

\begin{tabular}{|c|c|c|c|c|c|c|}
\hline Themes & Categories & Codes & Length & Count & $\begin{array}{c}\text { Weighted } \\
\text { Percentage (\%) }\end{array}$ & Total \\
\hline \multirow{13}{*}{$\begin{array}{l}\text { Political } \\
\text { Factors }\end{array}$} & \multirow{13}{*}{$\begin{array}{l}\text { Regulations } \\
\text { and Rules }\end{array}$} & Process & 7 & 144 & 1.03 & \multirow{13}{*}{7.69} \\
\hline & & Take & 4 & 386 & 2.04 & \\
\hline & & Partnership & 11 & 76 & 0.91 & \\
\hline & & Work & 4 & 197 & 0.85 & \\
\hline & & Level & 5 & 76 & 0.60 & \\
\hline & & High & 4 & 26 & 0.31 & \\
\hline & & Part & 4 & 67 & 0.31 & \\
\hline & & View & 4 & 56 & 0.33 & \\
\hline & & Think & 5 & 59 & 0.31 & \\
\hline & & Certain & 7 & 25 & 0.29 & \\
\hline & & Related & 7 & 43 & 0.26 & \\
\hline & & Units & 5 & 34 & 0.23 & \\
\hline & & Name & 4 & 40 & 0.22 & \\
\hline
\end{tabular}




\subsubsection{Conclusion of the Interviews Analysis}

The interviews were read in depth, codes were extracted, and related codes were intermingled into one category. Then related categories were integrated into one theme representing the main themes of the current research. Data conducted by the interviews were analyzed thematically and in terms of content. It could be concluded that factors which may affect the successful implementation of a PPP in the Egyptian educational context are codes related to political, legal, economic and financial, managerial and operational aspects. This means that political, legal, economic and financial, managerial and operational factors have an important influence on the implementation of successful PPP in Egypt. In addition, some interviewees agreed that this might differ from one firm to another according to the type of industry.

\subsection{Questionnaire Analysis}

This section introduces the empirical study with the main findings and results after running the data analysis. A descriptive analysis is presented for research variables, also normality testing for the research variables. Correlation and regression using SEM test the hypothesis for the research. Analysis is conducted for the purpose of hypothesis testing using SPSS and Amos. Finally, the conclusion section represents a summary of the main findings of the current research.

\subsubsection{Descriptive Analysis}

In the following section, means, standard deviations and frequency statistical analysis is conducted on the research variables. Table 8 shows the means and standard deviations for the research variables. It could be observed that the mean and the frequencies of most responses are in the agreement zone, as the mean values for the research variables political, legal, economic and financial, managerial and operational, and successful PPPs are 3.6602, 3.5971, 3.6796, 3.6505, and 3.9854 respectively.

Table 8. Descriptive analysis for the research variables.

\begin{tabular}{ccccccccc}
\hline & \multirow{2}{*}{} & \multirow{2}{*}{ Mean } & Std. Deviation & \multicolumn{5}{c}{ Frequency } \\
\cline { 6 - 9 } & & & & $\mathbf{1}$ & $\mathbf{2}$ & $\mathbf{3}$ & $\mathbf{4}$ & $\mathbf{5}$ \\
\hline Political & 206 & 3.6602 & 0.79699 & 4 & 12 & 52 & 120 & 18 \\
\hline Legal & 206 & 3.5971 & 0.87110 & 11 & 8 & 46 & 129 & 12 \\
\hline Economic and Financial & 206 & 3.6796 & 0.83478 & 4 & 12 & 55 & 110 & 25 \\
\hline Managerial and Operational & 206 & 3.6505 & 0.84633 & 7 & 10 & 50 & 120 & 19 \\
\hline Successful PPP & 206 & 3.9854 & 0.92382 & 4 & 12 & 29 & 99 & 62 \\
\hline
\end{tabular}

\subsubsection{Validity and Reliability Test}

A validity and reliability test is conducted to be sure the questionnaire statements are phrased in a well format. It could be noted from Table 9 that items $1,4,5$, and 8 of managerial and operational factors all have weak factor loadings of less than 0.4 . Therefore, these items were excluded from the analysis.

\subsubsection{Testing Research Hypothesis}

As the formal and informal tests show that the data under study are not normally distributed, Spearman's correlation coefficient is used. Table 10 shows the correlation matrix for the relationship between independent variables: political, legal, economic and financial, managerial and operational, and successful PPP. According to [56], if the value of the correlation coefficient (r) showed a positive (+) 1.0, there is a positive correlation between the two variables. The results indicate that the relationship is significant positive between political, legal, economic and financial, managerial and operational 
antecedents, and successful PPP, as the corresponding $p$-values are less than 0.05 and correlation coefficients are $0.665,0.672,0.667$, and 0.706 respectively.

Table 9. Validity and reliability tests for the research variables of pilot study.

\begin{tabular}{|c|c|c|c|c|c|}
\hline Variables & KMO & AVE & Cronbach's Alpha & Items & Factor Loading \\
\hline \multirow{4}{*}{ Successful PPP } & \multirow{4}{*}{0.858} & \multirow{4}{*}{80.374} & \multirow{4}{*}{0.918} & S1 & 0.800 \\
\hline & & & & S2 & 0.775 \\
\hline & & & & S3 & 0.829 \\
\hline & & & & S4 & 0.811 \\
\hline \multirow{5}{*}{ Political } & \multirow{5}{*}{0.801} & \multirow{5}{*}{73.952} & \multirow{5}{*}{0.911} & P1 & 0.713 \\
\hline & & & & P2 & 0.775 \\
\hline & & & & P3 & 0.794 \\
\hline & & & & $\mathrm{P} 4$ & 0.720 \\
\hline & & & & P5 & 0.696 \\
\hline \multirow{4}{*}{ Legal } & \multirow{4}{*}{0.849} & \multirow{4}{*}{77.737} & \multirow{4}{*}{0.904} & L1 & 0.746 \\
\hline & & & & L2 & 0.808 \\
\hline & & & & L3 & 0.758 \\
\hline & & & & L4 & 0.796 \\
\hline \multirow{3}{*}{ Economic and Financial } & \multirow{3}{*}{0.738} & \multirow{3}{*}{80.577} & \multirow{3}{*}{0.879} & F1 & 0.810 \\
\hline & & & & F2 & 0.832 \\
\hline & & & & F3 & 0.775 \\
\hline \multirow{9}{*}{$\begin{array}{l}\text { Managerial and } \\
\text { Operational }\end{array}$} & \multirow{9}{*}{0.833} & \multirow{9}{*}{75.883} & \multirow{9}{*}{0.918} & M1 & Deleted \\
\hline & & & & M2 & 0.722 \\
\hline & & & & M3 & 0.710 \\
\hline & & & & M4 & Deleted \\
\hline & & & & M5 & Deleted \\
\hline & & & & M6 & 0.686 \\
\hline & & & & M7 & 0.859 \\
\hline & & & & M8 & Deleted \\
\hline & & & & M9 & 0.817 \\
\hline
\end{tabular}

Table 10. Correlation matrix between independent variables and successful PPP.

\begin{tabular}{|c|c|c|c|c|c|c|c|}
\hline & & & 1. & 2. & 3. & 4. & 5. \\
\hline \multirow{15}{*}{ Spearman's rho } & \multirow{3}{*}{ 1. Political } & Correlation Coefficient & 1.000 & & & & \\
\hline & & Sig. (2-tailed) & & & & & \\
\hline & & $\mathrm{N}$ & 206 & & & & \\
\hline & \multirow{3}{*}{ 2. Legal } & Correlation Coefficient & $0.553 * *$ & 1.000 & & & \\
\hline & & Sig. (2-tailed) & 0.000 & & & & \\
\hline & & $\mathrm{N}$ & 206 & 206 & & & \\
\hline & \multirow{3}{*}{$\begin{array}{l}\text { 3. Economic and } \\
\text { Financial }\end{array}$} & Correlation Coefficient & $0.647^{* *}$ & $0.651^{* *}$ & 1.000 & & \\
\hline & & Sig. (2-tailed) & 0.000 & 0.000 & & & \\
\hline & & $\mathrm{N}$ & 206 & 206 & 206 & & \\
\hline & \multirow{3}{*}{$\begin{array}{l}\text { 4. Managerial and } \\
\text { Operational }\end{array}$} & Correlation Coefficient & $0.682 * *$ & $0.623 * *$ & $0.676^{* *}$ & 1.000 & \\
\hline & & Sig. (2-tailed) & 0.000 & 0.000 & 0.000 & & \\
\hline & & $\mathrm{N}$ & 206 & 206 & 206 & 206 & \\
\hline & \multirow{3}{*}{ 5. Successful PPP } & Correlation Coefficient & $0.665^{* *}$ & $0.672 * *$ & $0.667^{* *}$ & $0.706^{* *}$ & 1.000 \\
\hline & & Sig. (2-tailed) & 0.000 & 0.000 & 0.000 & 0.000 & \\
\hline & & $\mathrm{N}$ & 206 & 206 & 206 & 206 & 206 \\
\hline
\end{tabular}

**. Correlation is significant at the 0.01 level (2-tailed). 
Table 11 shows the SEM analysis of the impact of the independent variables: political, legal, economic and financial, managerial and operational, and successful PPPs. It could be noted that there is a significant effect of political, legal, economic and financial, and managerial and operational on successful PPPs as the estimated values are $0.255,0.271,0.244$, and 0.280 and $p$-values are less than 0.000 . Furthermore, the R square is 0.826 , which means that the model explains $82.6 \%$ of the variation in successful PPPs.

Table 11. Structural equation modeling (SEM) analysis of independent variables on successful PPPs.

\begin{tabular}{cccccc}
\hline Dependent Variables & & Independent Variables & Estimate & $p$ & $\mathbf{R}^{\mathbf{2}}$ \\
\hline Successful PPP & $\leftarrow$ & Political & 0.255 & 0.006 & \\
\cline { 1 - 5 } Successful PPP & $\leftarrow$ & Legal & 0.271 & 0.001 & \multirow{2}{*}{0.826} \\
\cline { 1 - 5 } Successful PPP & $\leftarrow$ & Economic and Financial & 0.244 & 0.045 & \\
\cline { 1 - 5 } Successful PPP & $\leftarrow$ & Managerial and Operational & 0.280 & 0.001 & \\
\hline
\end{tabular}

The model fit indices: $\mathrm{CMIN} / \mathrm{DF}=1.926, \mathrm{GFI}=0.859, \mathrm{CFI}=0.959, \mathrm{AGFI}=0.817$ and $\mathrm{RMSEA}$ $=0.067$ are all within their acceptable levels [38]. The SEM model conducted for the effect of the Independent Variables on Successful PPP is illustrated in Figure 3.

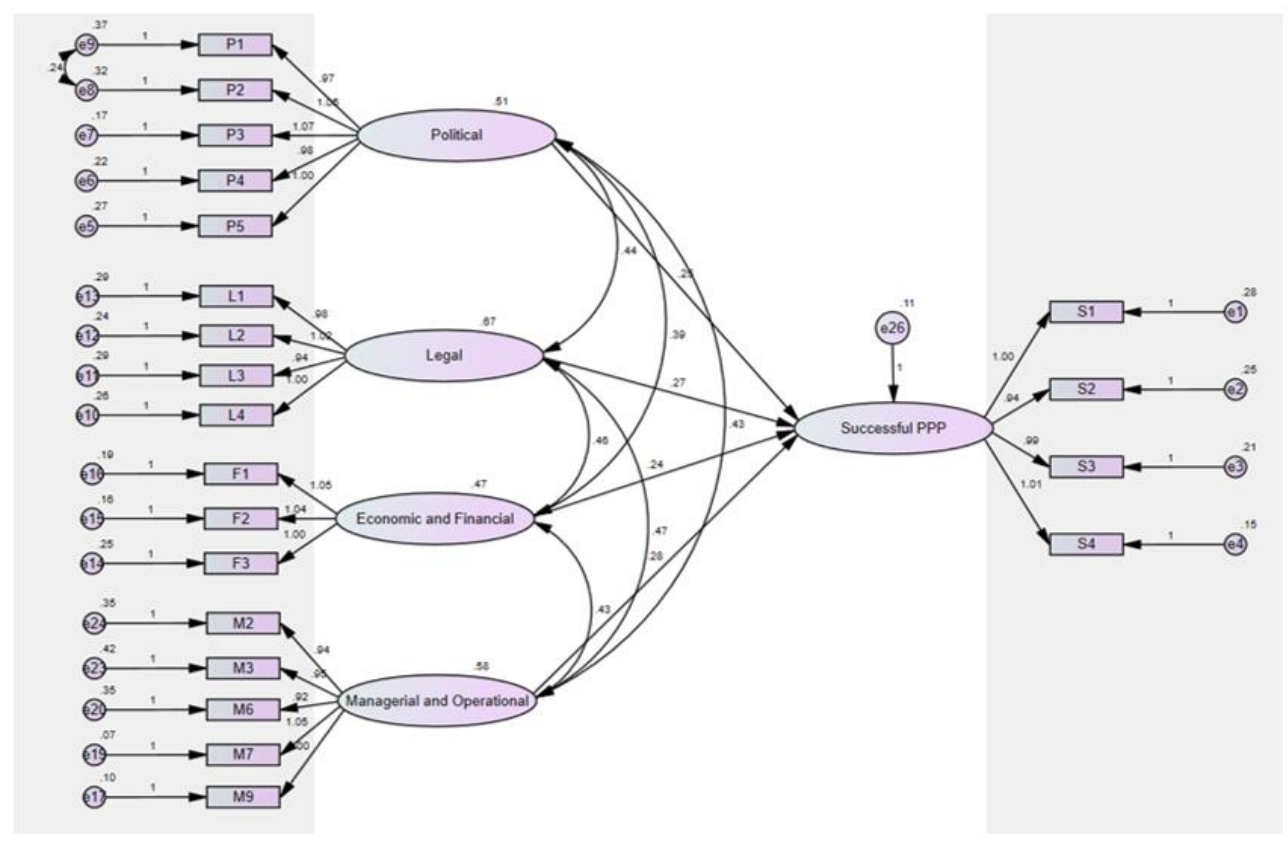

Figure 3. SEM model.

According to the estimated values of the independent variables, political, legal, economic and financial, managerial and operational factors, they can be ranked as follows; 1- Managerial and Operational factors, 2- Legal Factors, 3- Political Factors, 4- Economic and Financial Factors. Therefore, it is concluded that managerial and operational factors are the most significant factors that affect the successful implementation of PPPs.

\subsubsection{Conclusion of Questionnaire Analysis}

The data were analyzed empirically to test the research hypotheses by measuring the variables concluded from the literature review through a descriptive, correlation, and regression analysis using SPSS and Amos. Table 12 shows a summary of the conducted analysis. 
Table 12. Summary of research hypotheses.

\begin{tabular}{cll}
\hline Hypothesis & \multicolumn{1}{c}{ Description } & Results \\
\hline H1 & There is a significant relation between Political and Successful PPP & Fully Supported \\
\hline H2 & There is a significant relation between Legal and Successful PPP & Fully Supported \\
\hline H3 & There is a significant relation between Economic and Financial and Successful PPP & Fully Supported \\
\hline H4 & There is a significant relation between Managerial and Operational and Successful PPP & Fully Supported \\
\hline
\end{tabular}

\section{Conclusions and Recommendations}

This research was intended to enhance understanding of CSFs that affect PPPs' successful implementation in the education sector in Egypt. A CSF model was proposed to guide research on PPPs' successful implementation and the interview and survey results were analyzed with the aim to explore the CSFs and PPP successful implementation. Subsequently, this research offered insights into the relationships between the CSFs and PPP successful implementation. The mixed method, i.e., qualitative and quantitative research methodology, was used in this study. The results showed that a set of four CSFs groups which are political, legal, economic and financial as well as managerial and operational have a positive significant impact on successful PPP implementation in education in Egypt.

To conclude, the overall findings of this research are consistent with previous studies conducted to identify the CSFs for PPPs' successful implementation i.e., the political, legal, economic and financial, as well as managerial and operational factors have significant influence on successful implementation of PPP in Egypt in the education sector. However, the difference appears in the ranking importance of these factors. According to the SEM model conducted, the independent variables of successful PPPs can be ranked as follows; 1- Managerial and Operational factors, 2- Legal factors, 3- Political factors, 4- Economic and financial factors. Consequently, it is concluded that managerial and operational factors are the most significant factors that affect the successful implementation of a PPP. These results confirm other studies such as Jefferies [18] and Kang [46] that have found that factors relating to managerial aspects are the most important. Nevertheless, these results do not consist with other studies. For example, Yang et al. [38] identified economic and financial factors as the most important factors; Babatunde et al. [51] findings showed that political factors are most important to the private investors while managerial factors are most important to the public sector; Diba [27] results indicated that legal factors are the most important. The difference in these results can be explained as follows.

First, the majority of the interviewees indicate that success of PPP in education in Egypt depends on the management of the project that has to be given to the private sector, which is more capable of operating such projects, and a number of the survey respondents through their written remarks confirm this.

Second, some interviewees highlighted that one of the barriers that would hinder PPP successful implementation in the education sector in Egypt is the legal framework. They argued that in Egypt, we have many laws for regulating the educational process; however, we ought to have one simple law that would open the doors for people to work freely. Moreover, others argued that the presence and implementation of laws such as arbitration laws for dispute resolution would encourage the private sector to enter into PPP projects.

Third, although political factors are important for PPP project's success they were not ranked first. According to the interviewees, the efforts of the Egyptian government for developing an explicit policy to support and encourage PPP in all sectors of the economy are so obvious. This is evident in many of Egypt's Vision 2030 explicit statements, the enactment and amendment of a number of laws and the establishment of a competent central PPP unit in 2006 in the Ministry of Finance as previously discussed.

Finally, the economic and financial factors were perceived as less important, and this could be explained by looking at some of the interviewees' answers. According to one of the survey respondents, the effect of these factors is logic and has an impact on any investment. Another was of the view 
that macroeconomic concerns such as unstable inflation and exchange rates could be covered in the allocation of risks and investment protection guarantees such as minimum revenue. It was also argued that with majority of international investors migrating from the developed world and into developing countries searching for new potential business, Egypt with its growing population and booming capital markets and insurance and banking industry is ripe for the picking.

As for the implication of the research results and findings, they can be stated as follows:

- The government can encourage the commissioning of PPP projects and overcome resistance to these projects by giving more clear and explicit indicators of the government's policy and its intention to meet its contractual obligations. This can be done through the incentives that the government provides. For example, two of the interviewees argued that the incentives that the government provides either in the form of tax relief, granting lands necessary for project, minimum revenue guarantee or partial risk guarantees is considered crucial for encouraging investment and securing finance from the private sector.

Moreover, in spite of the efforts made by the Egyptian government for developing an explicit policy to support and encourage PPPs in all sectors of the economy, there is still no clear and planned program for PPP projects in education in Egypt. Only two pilot projects are conducted by the central PPP unit and a number of programs created through mutual efforts and agreement between the private sector and public education institutions (e.g., mutual education programs). The presence of a clear program and plan for PPP projects in the education sector in Egypt would encourage the private sector to invest in these projects. This clear program would provide the private sector investor with the direction, clarity and guidance essential to create the confidence needed to invest in new markets and programs. It would also provide the leadership necessary for public sector employees to embrace PPP projects in education sector. Moreover, the establishment of satellite PPP units in the line ministries that are equipped with highly qualified and experienced personnel would support the successful implementation of these projects.

- The presence of a favorable legal and regulatory framework as well as an alternative dispute resolution systems as arbitration may be a critical factor for fostering partnership between public and private sectors. One of the interviews respondents highlighted that one of the barriers that would hinder PPPs' successful implementation in the education sector in Egypt is the legal framework. He argued that in Egypt, we have many laws for regulating the educational process; we want to omit these laws completely and have one simple law that would open the doors for people to work freely. Moreover, another two respondents argued that the presence and implementation of laws such as arbitration law to face disputes' resolution could encourage the private sector to enter into PPP projects.

If we have an overview of Egypt's legal framework we find that Law no. 67 of 2010 has been enacted and amended to regulate PPP projects. This would help in preventing and curbing corruption. Moreover, it gives assurances to reputable bidders (both local and foreign) that a due process is in place and that the government of Egypt is serious about following the PPP programs in an effective manner. Giving confidence to potential bidders will increase the number willing to participate, improve competition and thereby project performance. However, the procedures of implementation are crucial for ensuring the effective implementation of the law. Thus, it is important that the government ensures the presence of persons who have the competence and expertise to implement law.

Furthermore, arbitration is arising as an essential method for settling investment and commercial disputes in Egypt. The promulgation of Arbitration Law no. 27 of 1994 was a crucial achievement in providing a comprehensive framework for the arbitration process in Egypt. Thus, it would be of great importance that the government allow the usage and inclusion of arbitration clauses 
in the PPP contracts in the education sector as this would encourage private sector investors especially foreigners to enter this partnership.

- The primary consideration for private partners in PPP is the rich returns. Therefore, to establish a PPP in an economy, a market must exist in a way that permits PPP projects to make profits in order to get involved, the private sector has the intention to participate, and the financial market has the will to invest. One of the interviewees reported that the ability to make profits in the education sector and the size of the target segment (demand) is critical for PPP success in education. Similarly, one more interviewee argued that the sustainability of PPP project is the indication of success, and this sustainability occurs when there is income generation. Egypt with its growing population and booming capital markets and insurance and banking industry is ripe for the picking. This leads these factors to be perceived as important areas for future research. The government also has to work on formulating financial models that would ensure the existence of rich returns that would allow sustainability of PPP projects.

- The existence of a favorable, supporting managerial and operating environment is positively related to PPP success in the educational sector in Egypt. This favorable and supporting environment can be reached through a number of factors: transparency in the procurement process, competitive procurement process, project technical feasibility, strong private consortium, appropriate risk allocation, shared authority, thorough and realistic assessment of costs and benefits, good governance and public/community support. This was confirmed by the research findings in both the qualitative and quantitative methods. This was evident in a number of the interviewees' statements: one of the respondents said that an essential factor is to work together as partners. Another respondent stated that a clear financial model held by the private sector is a critical factor however; the public sector must have the technical capacities that could review this financial model because this is a partnership. One more respondent confirmed that the absence of trust between the two sectors would be a crucial barrier for partnership success.

Consequently, suitable contractors must be available with the technical knowledge to manage complex projects and possess the will to make long-term investments in a particular market. Similarly, investors with an appropriate level of understanding of the mechanics of a PPP and the ability to participate in a viable consortium have to be involved to guarantee the success of the PPP project. Moreover, the Egyptian government needs to develop a clear and effective policy on unsolicited proposals from the private sector. According to the World Bank [29], this would prevent non-transparent behavior, moreover, the absence of clarity and transparency in dealing with unsolicited proposals may lead to projects that yield low value for money.

- Furthermore, the digital learning environment of the next generation introduces many challenges for educational institutions due to its completely new methods of teaching and learning. Consequently, facing these challenges demands cooperation to collectively control and govern resources as well as providing the infrastructure needed to enhance innovation and serve institutions' mission. In addition, good governance in managing PPP in education in Egypt seems essential, as it would guarantee that the involvement of the private sector achieves the maximum benefit for society.

Therefore, in order to help in the successful implementation of PPP projects in education in Egypt, the research propose the following recommendations:

The first recommendation from this research is to have a clear, common and integrated vision for the implementation of PPP projects as an element of the development plan for the education sector in Egypt. The second recommendation is the activation of the PPP central unit and its satellite units in the line ministries, through setting a clear PPP program based on clear policy and strategy. The third recommendation is that the government should consider the inclusion of arbitration clauses in the PPP agreements in the education sector. The fourth recommendation is that the Egyptian 
government needs to develop a clear and effective policy on unsolicited proposals from the private sector. The fifth recommendation is that the private sector that possesses the specific ability to run education projects should be given more responsibility, leadership and initiatives by the government. The sixth recommendation is to increase the general awareness of PPP projects and management. The seventh recommendation from this research study is the need for the educational authorities to develop a database of historical PPP education projects and programs once they have been developed.

\section{Research Limitations and Future Directions}

As with all research, this research has several limitations. First, the researchers collected the data from two cities representing one country, Egypt. It is suggested that data are collected from another country (developed and/or developing) to compare the results and see if the finding of the current research, which is applied in Egypt, is similar when applied to another country. A second limitation for this research is the small sample used in the interviews; this is because handling more interviews caused a kind of redundancy in information, which prompted the researchers to stop collecting more data.

Author Contributions: Conceptualization, R.H.; methodology, R.H.; validation, N.K. and M.W.; formal analysis, R.H.; investigation, R.H.; resources, R.H.; data curation, R.H.; writing-original draft preparation, R.H.; writing-review and editing, R.H. and N.K.; supervision, N.K., M.W., and A.A.E.B.; project administration, R.H. All authors have read and agreed to the published version of the manuscript.

Funding: This research received no external funding.

Acknowledgments: With much appreciation, I would like to thank Abdallah Srour, Hani Helal and Mohamed A. Ragheb who supported me during my journey with this research.

Conflicts of Interest: The authors declare no conflict of interest.

\section{References}

1. Egypt Vision. 2030. Available online: http://mop.gov.eg/Vision/EgyptVision.aspx (accessed on 6 October 2019).

2. Afridi, M. PPPs in Global Education Policy: Looking at the Case of the Egyptian Education Initiative. In The Power of Resistance; Emerald Publishing Limited: Bradford, UK, 2017; pp. 165-188. [CrossRef]

3. Ghayat, M. Signing PPP Contracts between the Government and Investors to Build and Maintenance Schools. 2019. Available online: https://www.masrawy.com/news/news_egypt/details/2019/1/16/1497659/(accessed on 9 February 2019).

4. Chatham House. MENA Programme Meeting Summary: Education in Egypt; Chatham House: London, UK, 2012; Available online: http://www.chathamhouse.org/sites/default/files/public/Research/Middle\% 20East0112egyptedu_summary.pdf (accessed on 26 October 2019).

5. Patrinos, H.; Barrera-Osorio, F.; Guaqueta, J. The Role and Impact of Public-Private Partnerships in Education; World Bank: Washington, DC, USA, 2009; Available online: https://ppp.worldbank.org/public-privatepartnership/library/role-and-impact-public-private-partnerships-education (accessed on 24 October 2019).

6. Tilak, J.B.G. Public Private Partnership in Education, Discussion Paper Series No. 3/2016, The Head Foundation Sri Untari, “Public-Private Partnerships in Improving the Quality of Education for the Poor in Indonesia". Public Policy and Administration Research. 2016, Volume 6. No.6, ISSN 2224-5731(Paper) ISSN 2225-0972(Online). Available online: www.iiste.org (accessed on 23 February 2019).

7. Bhanji, Z. Transnational corporations in education: Filling the governance gap through new social norms and market multilateralism? Glob. Soc. Educ. 2008, 6, 5573. [CrossRef]

8. World Economic Forum. Global Education Initiative; World Economic Forum: Geneva, Switzerland, 2007.

9. ILO. CSR_Industrial Leaders of Egypt_-Towards Creating Shared Value_Volume II: Food Industry; International Labour Organization Publications: Geneva, Switzerland, 2015.

10. Tobenkin, D. Fast Food Chain Dishes up Employment. 2011. Available online: https://www.shrm.org/ resourcesandtools/hr-topics/global-hr/pages/fastfooddegrees.aspx (accessed on 25 September 2019).

11. El Din, M. Will the Private Sector Save Egypt's Education Plea? In MadaMasr. 2016. Available online: https://www. madamasr.com/en/2016/11/02/feature/politics/will-the-private-sectorsaveegypts-education-plea/ (accessed on 23 February 2019). 
12. Egypt Today. Egypt's First School for Applied Technology Opens Door for Applicants. 2018. Available online: https://www.egypttoday.com/Article/1/53258/Egypt-s-first-school-for-applied-technology-opensdoor-for (accessed on 2 December 2019).

13. Egypt Independent. Egypt to Establish Its First School for Jewelry. 2019. Available online: https://egyptindependent. com/egypt-to-establish-its-first-school-specialized-in-jewelry-manufacturing/ (accessed on 27 November 2019).

14. Ministry of Education. Education 2.0. Available online: https://moenewsegypt.com/en/education_systems/5 (accessed on 2 December 2019).

15. UNICEF Egypt. UNICEF Egypt Collaborates with Partners to Further Develop the Education System that Provides Egypt's Children, Adolescent and Youth, with Quality and Relevant Learning Opportunities that Change Their Lives and the Lives of Their Children. 2017. Available online: https://www.unicef.org/egypt/ education (accessed on 2 December 2019).

16. Kwak, Y.H.; Chih, Y.; Ibbs, C.W. Towards a Comprehensive Understanding of PPPs for Infrastructure Development. Calif. Manag. Rev. 2009, 51, 51-78. [CrossRef]

17. Ngiri, E.G. Factors Influencing Performance of Rural Development Community-Based Projects in Murang'a South District, Murang' a County. Kenyatta University. (Online). 2012. Available online: http://ir-library.ku. ac.ke/handle/123456789/9857 (accessed on 13 June 2019).

18. Jefferies, M. Critical Success Factors of Public Private Sector Partnerships: A Case Study of the Sydney SuperDome. Eng. Constr. Archit. Manag. 2006, 13, 451-462. [CrossRef]

19. Yitmen, I.; Akiner, I.; Tekce, I. Applicability of Second Generation Public Private Partnership Projects in Turkey: A Conceptual Framework. 2018. Available online: https://www.researchgate.net/publication/269100681 (accessed on 13 June 2019).

20. Klijn, E.H. Public Private Partnerships: Deciphering meaning, message and phenomenon. In International Handbook of PPP; Hodge, G., Grev, C., Eds.; Edgar Elgar: Cheltenham, UK, 2010; pp. 68-80.

21. Osei-Kyei, R.; Chan, A.P.C. Review of studies on the Critical Success Factors for Public-Private Partnership (PPP) projects from 1990 to 2013. Int. J. Proj. Manag. 2015, 33, 1335-1346. [CrossRef]

22. Hardcastle, C.; Edwards, P.J.; Akintoye, A.; Li, B. Critical Success Factors for PPP/PFI Projects in the UK Construction Industry: A Factory Analysis Approach. In Proceedings: Public Private Partnerships Opportunities and Challenges; Hong Kong Convention and Exhibition Centre: Hong Kong, China, 2005; p. e83.

23. Jamali, D. Success and failure mechanisms of public private partnerships (PPPs) in developing countries: Insights from the Lebanese context. Int. J. Public Sect. Manag. 2004, 17, 414-430. [CrossRef]

24. Pongsiri, N. Regulation and Public Private Partnerships. Int. J. Public Sect. Manag. 2002, 15, 487-495. [CrossRef]

25. International Monetary Fund. Public-Private Partnerships; Fiscal Affairs Department: Washington, DC, USA, 2004.

26. Khan, A. Growth, Employment and Poverty Reduction. 2007. Available online: https://www.un.org/en/desa/ products/working-papers?page $=4$ (accessed on 13 June 2019).

27. Diba, H. Critical Success Factors for Public Private Partnership Projects in the Kenyan Road Sub-Sector. Master's Thesis, University of Nairobi, Nairobi, Kenya, 2012.

28. Ong'olo, D.O. Public Private Partnerships (PPP) Practice and Regulatory Policy in Kenya. In The Institute of Economic Affairs; IEA: Nairobi, Kenya, 2006.

29. World Bank. Procuring Infrastructure Public-Private Partnerships; World Bank Report; World Bank Group, PPP LRC: Washington, DC, USA, 2018.

30. Zhang, X.Q. Criteria for selecting the private-sector partner in public-private partnerships. J. Constr. Eng. Manag. 2005, 131, 631-644. [CrossRef]

31. Li, B.; Akintoyc, A.; Edwards, P.J.; Hardcastle, C. Critical Success Factors for PPP/PFI Projects in the UK Construction Industry: Factor Analysis Approach. Constr. Manag. Econ. 2005, 23, 459-471. [CrossRef]

32. Sarmento, J.M.; Renneboog, L. Anatomy of public-private partnerships: Their creation, financing and renegotiations. Int. J. Manag. Proj. Bus. 2016, 9, 94-122. [CrossRef]

33. Nelson, J.; Zaldek, S. Partnership Alchemy: New Social Partnerships in Europe; The Copenhagen Centre: Copenhagen, Denmark, 2000.

34. Kline, R.B. Principles and Practice of Structural Equation Modeling, 3rd ed.; Guilford Press: New York, NY, USA, 2011.

35. Saunders, M.; Lewis, P.; Thornhill, A. Research Methods for Business Students, 7th ed.; Financial Times; Prentice Hall: Harlow, UK, 2016.

36. Bryman, A.; Emma, B. Business Research Method, 3rd ed.; Oxford University Press: New York, NY, USA, 2011. 
37. Kwofie, T.E.; Afram, S.; Botchway, E. A critical success model for PPP public housing delivery in Ghana. Built Environ. Proj. Asset Manag. 2016, 6, 58-73. [CrossRef]

38. Yang, Y.; Wang, Y.; Hou, Y. On the Development of Public-Private Partnerships in Transitional Economies: An Explanatory Framework. Public Adm. Rev. 2013, 73, 301-310. [CrossRef]

39. Verhoest, K.; Petersen, O.H.; Scherrer, W.; Soecipto, M.R. How Do Governments Support the Development of Public Private Partnerships? Measuring and Comparing PPP Governmental Support in 20 European Countries. Transp. Rev. 2015, 35, 118-139. [CrossRef]

40. OECD. Public-Private Partnerships: In Pursuit of Risk Sharing and Value for Money. 2008. Available online: https:// www.oecd.org/gov/budgeting/public-privatepartnershipsinpursuitofrisksharingandvalueformoney.htm (accessed on 13 June 2019).

41. Baxter, D. 10 Important Questions to Ask The Public Sector When Pursuing a PPP Procurment. Published on Infrastructure and Public Private Partnerships. 2017. Available online: https://blogs.worldbank.org/ppps/10important-questions-ask-public-sector-when-pursuing-ppp-procurement (accessed on 13 June 2019).

42. UNESCO. Education for Sustainability_From Rio to Johannesburg: Lessons Learnt from A Decade of Commitment; UNESCO: Paris, France, 2002.

43. Ossman, S.A. Private Sector Partnership in Public Service Sector between Theory and Application; Dar Pharos: Alexandria, Egypt, 2019.

44. Muhammad, Z.; Johar, F. Critical success factors of public-private partnership projects: A comparative analysis of the housing sector between Malaysia and Nigeria. Int. J. Constr. Manag. 2019, 19, 257-269. [CrossRef]

45. Grimsey, D.; Lewis, M.K. Public Private-Partnerships: The Worldwide Revolution in Infrastructure Provision and Project Finance; Edward Elgar: Cheltenham, UK, 2004.

46. Kang, S.; Mulaphong, D.; Hwang, E.; Chang, C. Public-private partnerships in developing countries: Factors for successful adoption and implementation. Int. J. Public Sect. Manag. 2018. [CrossRef]

47. Hammami, M.; Ruhashyankiko, J.-F.; Yehoue, E. Determinants of Public-Private Partnerships in Infrastructure. IMF Work. Pap. 2006, 6. [CrossRef]

48. European Investment Bank. The European Investment Bank and Public Private Partnerships. 2000. Available online: https://www.eib.org/attachments/efs/efr_2010_v04_en.pdf (accessed on 13 June 2019).

49. Chan, A.P.C.; Lam, P.T.I.; Cheung, E.; Ke, Y. Critical Success Factors for PPPs in Infrastructure Developments: Chinese Perspective. J. Constr. Eng. Manag. 2010. [CrossRef]

50. Helmy, A.M. Investigating the Critical Success Factors for PPP Projects in Kuwait. Master's Thesis, Royal Institute of Technology, Stocholm, Sweden, 2011.

51. Babatunde, S.O.; Perera, S.; Zhou, L.; Udeaja, C. Barriers to public private partnership projects in developing countries. Eng. Constr. Archit. Manag. 2015, 22, 669-691. [CrossRef]

52. Cangiano, M.; Alier, M.; Anderson, B.; Hemming, R.; Petrie, M. Public-Private Partnerships, Government Guarantees, and Fiscal Risk; International Monetary Fund: Washington, DC, USA, 2006.

53. Li, B.; Akintoye, A. An Overview of Public-Private Partnership. In Public Private Partnerships; Akintoye, A., Beck, M., Hardcastle, C., Eds.; Blackwell Publishing: Oxford, UK, 2003; pp. 1-30.

54. Sarmento, J. Do public-private partnerships create value for money for the public sector? The Portuguese experience. OECD J. Budg. 2010, 1, 93-119.

55. Cesar, Q.; Ada, K.I. Worldwide Trends in Private Participation in Roads: Growing Activitiy, Growing Government Support; World Bank: Washington, DC, USA, 2008.

56. Veal, A.J. Business Research Methods: A Managerial Approach, 2nd ed.; Pearson Education: London, UK, 2005.

Publisher's Note: MDPI stays neutral with regard to jurisdictional claims in published maps and institutional affiliations.

(C) 2020 by the authors. Licensee MDPI, Basel, Switzerland. This article is an open access article distributed under the terms and conditions of the Creative Commons Attribution (CC BY) license (http://creativecommons.org/licenses/by/4.0/). 